\title{
DETERMINATION OF ANIONIC DETERGENT CONTENT IN GREYWATER
}

\author{
Réka LÓS ${ }^{1}$, Andrea IZBÉKI-SZABOLCSIK², Ildikó BODNÁR ${ }^{3}$ \\ University of Debrecen, Faculty of Engineering, Department of Environmental Engineering, Debrecen, Hungary \\ ${ }^{1}$ losrekaaa@gmail.com \\ ${ }^{2}$ szabolcsikandi@eng.unideb.hu \\ ${ }^{3}$ bodnari@eng.unideb.hu
}

\begin{abstract}
In this research we have improved a method for the determination of anionic detergent content (ANA) in greywater samples. Based on the earlier studies at the Department of Environmental Engineering at the University of Debrecen this new, more reliable method for ANA values is very effective. We examined the quantity of anionic detergent content in synthetic greywater samples with Hyamine reagent using a twophased titrimetric method. We added to the synthetic greywater samples phenolphthalein indicator, acid mixed indicator and chloroform. Next, we shook the mixture, and we produced two separated phases. We titrated the mixture with cation active Hyamine reagent. It was shown that the applied method is both representative and reliable.
\end{abstract}

Keywords: anionic detergent, greywater, two-phased titration.

\section{Introduction}

The freshwater supply of the Earth is decreasing as a result of rapid population growth and growing demand. Therefore it is necessary to look for opportunities as soon as possible to mitigate [1] and regulate our water consumption. One possible method for water saving, is the use of socalled greywater for example toilet flushing, irrigation of green yards, and car washing.

\section{Conception of greywater}

Greywater is generated as wastewater from the bath, washing, hand washing and dish washing, but not including water from the flush toilet. Greywater can contain a large amount of surfactant, so-called detergent as well, which it is necessary to remove before the reuse or the emission to water bases. The detergent content can vary based on the greywater resulting from shampoos, shower gels, liquid detergent and dish soap etc. in the household. According to Ghaitiad et al. [1], the anionic detergent (ANA) content of bathwater is typically 15 to $60 \mathrm{mgL}^{-1}$, ANA of greywater from washing is 40 to $120 \mathrm{mgL}^{-1}$, and ANA of greywater from kitchen sink is 40 to $60 \mathrm{mgL}^{-1}$. The composition of household generated greywater depends largely on the number of inhabitants, their age distribution, hygiene habits and geographical location. In the course of previous studies at the Department of Environmental Engineering at the University of Debrecen it was proved with adequate measurements, that the quality of greywater is very variable [2]. The aim of this research is to develop a suitable method for determination of these surfactants from the greywater samples, and to check later treatment solutions using an accurate knowledge of ANA content.

\section{Determination of detergent}

Surfactants are a group of chemical compounds that are able to reduce the surface tension of solvents, so nowadays they are widely used in different areas, e.g. in industry, in cosmetics prod- 
ucts, in household products and many other fields $[3,4]$. Detergents can be categorized according to their chemical structure into four groups, anionic, cationic, nonionic and amphoteric detergents [5, 6]. After use, the detergents and their products are placed in the sewage treatment plants with communal effluents and can be released into surface waters and dispersed in the environment through sludge disposal. The anthropogenic release of detergents into the environment may be harmful as it prevents oxygen diffusion in the waters and may cause algal blooms in high sulphate content too. They disturb sewage, drinking water purification and deteriorate the efficiency of selfcleaning procedures of surface water [7, 8].

\subsection{Determination opportunity of anionic detergent}

Several international recommendations (titrimetric, electroanalytical, and photometric) are also known for the determination of detergent content, using a diverse methodology to identify all the constituents of these materials [3]. Based on the earlier studies at the Environmental Engineering Department of University of Debrecen ANA values of greywater samples were measured in accordance with Hungarian Standard MSZ 44849: 1981. According to this standard, detergents form a blue complex in an acidic medium with a methylene blue indicator and dissolve in chloroform. Thus, they can be removed by extraction methods because the methylene blue remains insoluble in chloroform. The obtained extract's colour strength up to $2 \mathrm{mgL}^{-1}$ concentration is proportional of the anionic detergent quantity. The samples were diluted to have a detergent content of 0.4 to $2.0 \mathrm{mgL}^{-1}$. Quantitative determination of ANA detergents can be affected by the content of organic matter (> $\left.25 \mathrm{mgL}^{-1}\right)$ and nitrate concentration (> $\left.350 \mathrm{mgL}^{-1}\right)$ of greywater. In the examined greywater samples, the disturbing effects were successfully eliminated by dilution of the samples. However, not all water samples were measured over the detection limit due to dilution [9]. From this it can be seen that the measurement according to Hungarian Standard MSZ 44849: 1981 is very difficult, slow and expensive, and in some cases unreliable. Our applied method development efforts were greatly assisted by the using of synthetic greywater, which represents the average bath water samples in our region. Using the synthetic greywater with a permanent composition helps in the comparison of the results of our method development experiments. The aim of our research was to develop a unique method to measure the detergent content of greywater faster, more accurately and with a less polluting process using a simple titrimetric determination. In our experiments, we used the two-phase titrimetric method [10], which is based on ISO 2271: 1989 standard. The standard conditions are as follows: specified amount of sample is titrated in a sealable flask. Firstly we added a phenolphthalein indicator to the samples to adjust the $\mathrm{pH}$ value, which showed the light-pink colour appearance or disappearance. After that we added $5 \mathrm{~mL}$ acid mixed indicator to the sample, finally we added $5 \mathrm{~mL}$ chloroform. Next, the flask was sealed and shaken vigorously. After shaking the mixture, we got two separated phases. We titrated the mixture with cation active $0.004 \mathrm{molL}^{-1}$ Hyamine reagent. The equivalence point of the titration was marked by a colour change of the mixed indicator solution in the organic phase from pink to blue. (Figure 1., 2. and 3.) Based on the method, when a greenish-blue colour was detected, it indicated that the solution was overtitrated.

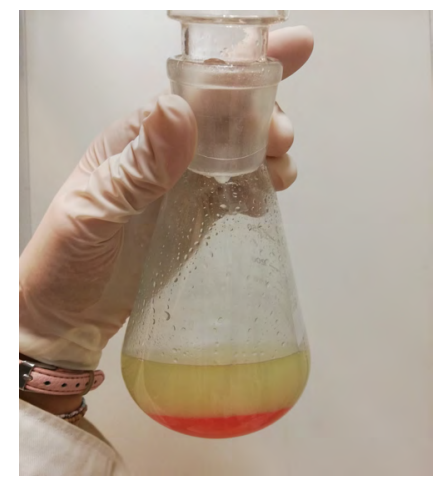

Figure 1. Before titration

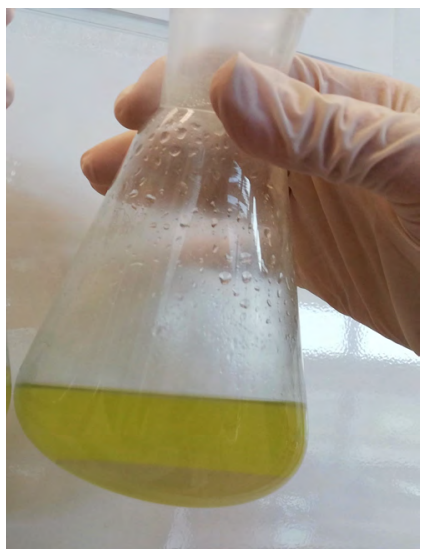

Figure 2. The equivalence point of the titration 


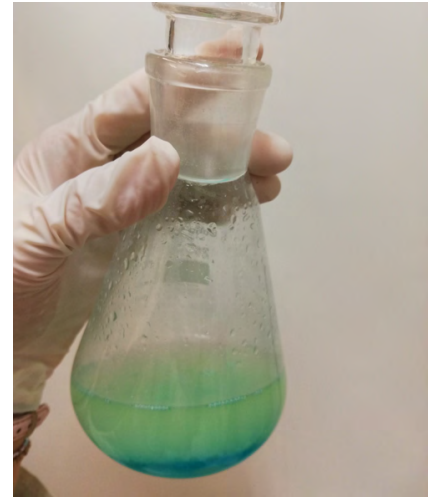

Figure 3. Over-titrated sample

\section{Result of research}

At the time of our method development, we first determined the ANA detergent content in the synthetic greywater sample using the method described in the international standard (see section 3.1), during which we detected a significant difference between the parallel measurements. We examined the ANA content of greywater samples $(50,100,200 \mathrm{~mL})$ by the following method: In $50 \mathrm{~mL}$ sample ANA value was $71.69 \mathrm{mgL}^{-1}$, in a sample of $100 \mathrm{~mL}$ it was $62.73 \mathrm{mgL}^{-1}$, and for 200 $\mathrm{mL}$ of samples it was $58.25 \mathrm{mgL}^{-1}$. Contrary to expectations, the detergent content decreased in the same synthetic bath water sample by increasing the sample volume, indicating instability of the method. New then raised the samples of chloroform quantity. In $100 \mathrm{~mL}$ samples we added 10 $\mathrm{mL}$ chloroform, and in the $200 \mathrm{~mL}$ samples we added $20 \mathrm{~mL}$ chloroform. In both cases the ANA detergent content was $58.25 \mathrm{mgL}^{-1}$. The method was representative, which was confirmed by the rise in chloroform-quantity. Then we investigated the content of several greywater samples to prove the base method stability for the greywater ANA-detergent content. We used three different synthetic greywater samples in the next step. In the first sample were the basic ingredients, while the second one contained half the amount of these ingredients, and the third one consisted of double the amount of the given ingredients. The result values demonstrated the method's reliability. In the first sample the ANA value was $53.77 \mathrm{mgL}^{-1}$, while in the second sample we detected half of this value

(26.88 $\mathrm{mgL}^{-1}$ ). In the third sample we detected double the amount of ANA (106.5 $\left.\mathrm{mgL}^{-1}\right)$. We titrated the synthetic greywater samples with a dilute Hyamine $\left(0.002 \mathrm{molL}^{-1}\right)$ reagent. It was shown that reducing the concentration of Hyamine reagent, the equivalent volume of Hyamine and ANA value also reduced. In the case of lower detergent content, we titrated the greywater samples with diluted Hyamine reagent, so we could follow the bigger reagent volume in a better way. We titrated the $50 \mathrm{~mL}$ greywater sample with $0.002 \mathrm{molL}^{-1}$ Hyamine reagent, and got the same ANA value $\left(\mathrm{mgL}^{-1}\right)$ then in the case of titration of $100 \mathrm{~mL}$ greywater sample with $0.004 \mathrm{molL}^{-1}$ Hyamine reagent, too.

\section{Conclusion}

It was shown that the applied two-phase titration is a very simple, quick and cheap method, with few tools and chemicals necessary. We suggested adding a double quantity of chloroform (5 mL instead $10 \mathrm{~mL}$ ), because with this alteration we were able to notice the end point and the colour change better. It was shown that half and duplicate amount of anionic detergent content actually resulted in half or twice the measured ANA values; so we can justify the reliability of the method in analysing greywaters. In the case of low anionic detergent samples, it may be useful to apply a lower concentration of the reference solution to $0.002 \mathrm{molL}^{-1}$ and titrate with a smaller sample volume.

\section{Acknowledgments}

The publication is supported by the EFOP-3.6.1-162016-00022 project. The project is cofinanced by the European Union and the European Social Fund.

\section{References}

[1] Ghaitidak D. M., Yadav K. D.: Characteristics and treatment of greywater $-A$ review. Environmental Science and Pollution Research, 20/5. (2013) 2795-2809.

https://doi.org/10.1007/s11356-013-1533-0

[2] Bodnar I., Szabolcsik A., Baranyai E., Uveges A., Boros N.: Qualitative Characterization of the Household Greywater in Northern Great Plain Region of Hungary. Environmental Engineering and Management Journal, Vol. 13/11. (2014) 2717-2724.

http://doi.org/10.30638/eemj.2014.302

[3] Mettler Toledo: Good Titriation Practice in surfactant titriation.

https://www.mt.com/dam/labdiv/campaigns/gp/ gtp/gtp_surfactant.pdf

[4] Galović O., Samardžić M., Petrušić S., Sak-Bosnar, M.: A new sensing material for the potentiometric determination of anionic surfactants in 
commercial products. International journal of electrochemical science 9/7. (2014) 3802-3818. http://www.electrochemsci.org/papers/ vol9/90703802.pdf

[5] Juhász É., Erős M. L.: Felületaktív anyagok zsebkönyve. (Surfactant's Pocketbook), Müszaki Könyvkiadó, Budapest, 1979.

[6] Barótfi I.: Szolgáltatástechnika. [Service technology]. Mezőgazda Kiadó, Budapest, 2001, 13-25, 153-161.

[7] Ying G. G.: Fate, behavior and effects of surfactants and their degradation products in the environment. Environment international, 32/3. (2006) 417-431.

https://doi.org/10.1016/j.envint.2005.07.004

[8] L. Sujbert: Tenzid xenobiotikumok az emberi környezetben, kölcsönhatásaik a humán ökoszisz- témával / Tensides in human environment and interactions between tensides and the human oecological system. Egészségtudomány 53/1. (2009). http://egeszsegtudomany.higienikus.hu/ cikk/2009_1/Sujbert.pdf

[9] Jolánkai G., Boros, N., Keczánné Üveges A., Fórián S., Kocsis D., Fehérné Baranyai E., Izbékiné Szabolcsik A., Bodnár I., Kalmár F.: Fenntartható energetika megújuló energiaforrások optimalizált integrálásával / Greywater treatment and reuse possibilities in houshold. University of Debrecen, Proceedings of DENZERO International Conference, Akadémiai Kiadó, Budapest, 2014.

[10] Cullum D. C. (Ed.): Introduction to surfactant analysis. Springer Netherlands, 1994.

https://doi.org/10.1007/978-94-011-1316-8 